University of Wollongong

Research Online

$1-1-2018$

\title{
Burn injury models of care: A review of quality and cultural safety for care of Indigenous children
}

\author{
Sarah Fraser \\ Flinders University \\ Julian Grant \\ Flinders University \\ Tamara Mackean \\ Flinders University, University of New South Wales \\ Kate Hunter \\ University of New South Wales \\ Andrew J A Holland \\ University of Sydney
}

See next page for additional authors

Follow this and additional works at: https://ro.uow.edu.au/ahsri

Research Online is the open access institutional repository for the University of Wollongong. For further information contact the UOW Library: research-pubs@uow.edu.au 


\title{
Burn injury models of care: A review of quality and cultural safety for care of Indigenous children
}

\author{
Abstract \\ Safety and quality in the systematic management of burn care is important to ensure optimal outcomes. \\ It is not clear if or how burn injury models of care uphold these qualities, or if they provide a space for \\ culturally safe healthcare for Indigenous peoples, especially for children. This review is a critique of \\ publically available models of care analysing their ability to facilitate safe, high-quality burn care for \\ Indigenous children. Models of care were identified and mapped against cultural safety principles in \\ healthcare, and against the National Health and Medical Research Council standard for clinical practice \\ guidelines. An initial search and appraisal of tools was conducted to assess suitability of the tools in \\ providing a mechanism to address quality and cultural safety. From the 53 documents found, 6 were \\ eligible for review. Aspects of cultural safety were addressed in the models, but not explicitly, and were \\ recorded very differently across all models. There was also limited or no cultural consultation \\ documented in the models of care reviewed. Quality in the documents against National Health and \\ Medical Research Council guidelines was evident; however, description or application of quality measures \\ was inconsistent and incomplete. Gaps concerning safety and quality in the documented care pathways \\ for Indigenous peoples' who sustain a burn injury and require burn care highlight the need for \\ investigation and reform of current practices.

\section{Publication Details} \\ S. Fraser, J. Grant, T. Mackean, K. Hunter, A. J.A. Holland, K. Clapham, W. J. Teague \& R. Q. Ivers, "Burn \\ injury models of care: A review of quality and cultural safety for care of Indigenous children", Burns 443 \\ (2018) 665-677.
}

\section{Authors}

Sarah Fraser, Julian Grant, Tamara Mackean, Kate Hunter, Andrew J A Holland, Kathleen F. Clapham, Warwick Teague, and Rebecca Q. Ivers 
TITLE

Burn injury models of care: a review of quality and cultural safety for care of Indigenous children

\section{AUTHORS}

Sarah Fraser

Flinders University, SA 5001 Australia

sarah.fraser@flinders.edu.au

Associate Professor Julian Grant

Flinders University, SA 5001 Australia

julian.grant@flinders.edu.au

Dr Tamara Mackean

Flinders University, SA 5001 Australia

The George Institute for Global Health, NSW 2050 Australia

tamara.mackean@flinders.edu.au

Dr Kate Hunter

The George Institute for Global Health, University of NSW, NSW 2050 Australia

khunter@georgeinstitute.org.au

Professor Andrew J A Holland

Sydney Medical School, The University of Sydney, The Children's Hospital at Westmead, NSW 2145 Australia

andrew.holland@health.nsw.gov.au

Professor Kathleen Clapham

Australian Health Services Research Institute, University of Wollongong NSW Australia 2522

kclapham@uow.edu.au

Associate Professor Warwick J Teague

The Royal Children's Hospital, University of Melbourne, VIC Australia 3052

warwick.teague@rch.org.au 
Professor Rebecca Ivers (CORRESPONDING AUTHOR)

The George Institute for Global Health, University of NSW, NSW 2050 Australia

rivers@georgeinstitute.org.au 


\section{ABSTRACT}

Safety and quality in the systematic management of burn care is important to ensure optimal outcomes. It is not clear if or how burn injury models of care uphold these qualities, or if they provide a space for culturally safe healthcare for Indigenous peoples, especially for children. This review is a critique of publically available models of care analysing their ability to facilitate safe, high-quality burn care for Indigenous children. Models of care were identified and mapped against cultural safety principles in healthcare, and against the National Health and Medical Research Council standard for clinical practice guidelines. An initial search and appraisal of tools was conducted to assess suitability of the tools in providing a mechanism to address quality and cultural safety. From the 53 documents found, 6 were eligible for review. Aspects of cultural safety were addressed in the models, but not explicitly, and were recorded very differently across all models. There was also limited or no cultural consultation documented in the models of care reviewed. Quality in the documents against National Health and Medical Research Council guidelines was evident; however, description or application of quality measures was inconsistent and incomplete. Gaps concerning safety and quality in the documented care pathways for Indigenous peoples' who sustain a burn injury and require burn care highlight the need for investigation and reform of current practices.

\section{HIGHLIGHTS}

- Gaps exist in the current burn injury models of care for Indigenous peoples

- Burn injury models of care do not explicitly address cultural safety

- Further work is needed to develop guidelines that appropriately manage cultural safety

\section{KEYWORDS}

- Burn

- Indigenous

- Safety

- Quality

- Models 


\section{INTRODUCTION}

Around the world, burn injury is a leading cause of morbidity[1], with children particularly at risk[2, 3]. People living in lower to middle income countries[1, 2, 4] and those who identify as Indigenous[4-8] are at greater risk of burn injury. Australian research has shown a greater proportion of Aboriginal than non-Aboriginal children sustain full thickness burns and burns affecting more than $20 \%$ of the total body area[9], similar to the increased incidence of burn injury for Aboriginal peoples living in non-metropolitan areas of Canada[5]. Health services continue to struggle to provide appropriate care to marginalised peoples[10] and this coupled with the over representation of burns in such populations, can challenge health systems globally to effectively resource and deliver suitable care.

Burn care is a collaborative and multidisciplinary process that, depending on burn severity, may require specialised facilities staffed by experts in burn care[11]. The specialised nature of burn care often results in hospital admission[1], frequent and sustained follow-up care and rehabilitation[12]. This specialist, multidisciplinary burn care required for good outcomes is guided by various system and service documents. One key set of documents include those relating to the clinical management of burn injury. These documents are usually discipline specific and guide health professionals in their provision and decision making regarding direct clinical care[13].

In contrast to these more clinical documents, guidance relating to overall system and service contexts for burn care is provided through burn injury models of care.

Models of care are not discipline specific nor do they have a specific clinical focus. A model of care is more of a multifaceted concept which broadly defines the way health services are enacted and delivered[14]. Models of care outline evidence-based, best practice patient care delivery through the application of a set of service principles across identified clinical streams and patient flow continuums [14]. While such principles are commonly recognised, ambiguity continues to exist regarding a strict definition of what constitutes a model of care [15]. For the purpose of this review, a model of care will be defined as an evidence informed philosophical document that provides an overarching framework for burn injury management for a given jurisdiction.

Though models of care for burn injury exist, what constitutes evidence based best practice burn care from this overall system and service perspective remains unclear. Primary research describes specific aspects of burn care, for example post-acute care and the use of 
telehealth[16, 17], education and follow-up[18] and the medical management of a burn injury[19]. Apart from a national review of burn care in the British Isles there is little literature that critiques and maps overall burn care for any given jurisdiction; the British Isles review stresses an urgent need for a coherent national burn care strategy[20]. Overall, it is unclear if existing international, or in particular Australian burn injury models of care purporting to represent best practice, are evidence informed, or have been evaluated to assess their ability to facilitate safe and high-quality care.

Safety and quality are implicit in models of care and are equally important for consumers of care as well as for health systems, services and professionals. High quality healthcare facilitates increased effectiveness and efficiencies[21]. This is true for the clinical component of burn management in regards to increased efficiencies in Australian jurisdictions[18, 22, 23]. Internationally, governmental commissions inform safety and quality in healthcare[2427]. In Australia, the Australian Safety and Quality Framework Health Care informs a vision for safety and quality in healthcare[28]. Frameworks such as these provide guidance and aim to achieve safety and appropriateness of healthcare in partnership with consumers[29]. Specific quality improvement documents exist for burn care[30]. How the concepts of safety and quality have been achieved, relate to or provide specific guidance to the systems and service management of Indigenous peoples with a burn injury remains unclear.

Differences in knowledge systems exist[31]. Science, a dominant global knowledge system, is in stark contrast to Indigenous knowledge systems of knowing, being and doing[32]. An important consideration where healthcare is directed at Indigenous people, is how safety may also relate to cultural competency and cultural safety. Cultural competency is the skill and capacity of healthcare professionals and systems to respond to cultural differences[33]. Cultural safety is an experiential, contextual theory developed by Maori in the New Zealand healthcare context to address the ways in which colonial practices, organisations and policy shape and negatively affect the health of Maori peoples[34]. The theory has since been adopted in other countries including Canada[35] and Australia[33], with evidence of improved healthcare outcomes [33].Similarly, outcomes following a burn injury are associated with many factors[36-40] and extends beyond simple issues of timely access to high-quality and specialist care. Within the context of burn care and for Indigenous peoples, cultural safety or lack thereof, also contributes to health outcome. As such, it is anticipated that if a burn injury model of care is of a high-quality and provides opportunities for health services and professionals to enact care that is culturally competent, there is potential for better health outcomes for those receiving care. Effective examples of culturally competent models of burn care are poorly described in the literature. 
This review aims to describe the existing Australian and international burn injury models of care that guide burn care management, particularly that of Indigenous children, and to critique and assess these models of care for their ability to facilitate safe, high-quality burn care.

\section{METHODS}

\section{Search strategy}

The search strategy included evidence syntheses and grey literature. The research focus and relevant search terms were developed iteratively in consultation with a supervisory group and refined during the literature search process. An initial search was conducted of the electronic databases: CINAHL, Scopus, Informit, and Web of Science. Keywords included: burn* AND "model of care" OR "practice guideline" OR "practice framework" OR "care standard". Additional key papers, guidelines, care standards, models of care and policy documents were sourced from health organisations and relevant associations as well as a search through reference lists and in Google Scholar. Literature was included if it reported on the system and service perspective of burn injury, with any focus on paediatrics or the care of Indigenous peoples. Because this review focuses on burn care from a systems and service perspective, literature limited to descriptions of the clinical management of burn injury were excluded, as were literature limited exclusively to adult patient care. This review reports in narrative form, a critique of documents from a wide variety of sources.

\section{Analysis framework}

In addition to the variable definitions of what constitutes a model of care, there also exists no specific tool for use to critique and appraise models of care. It is also important to acknowledge that Indigenous health knowledge cannot be verified by Western biomedical knowledge, nor can science be adequately assessed according to the tenets of Indigenous knowledge. Each is built on distinctive philosophies, methodologies and criteria[31]. The writing team consisted of Indigenous and non-Indigenous researchers: extensive discussion occurred to determine an analysis framework that interfaced the two knowledge systems. Interface research endeavours to eliminate the power imbalances and ensure equal embedding of knowledge systems. In the absence of a suitable overarching analysis framework to critique models of care and compounded by the complexities of different 
knowledge systems, two tools were chosen following an appraisal of different tools: one reflecting Indigenous theory and the other for analysis of scientific aspects.

Indigenous health knowledge was considered through the cultural safety principles (Table 1) in healthcare as described by Taylor and Guerin[41]. The principles enable a critique of the documents in terms of how they consider Indigenous ways of knowing, being and doing[32]. Deductive analysis was used to assess how burn injury models of care provide or not, opportunities for healthcare professionals to enact culturally competent care.

Western biomedical knowledge was critiqued through the National Health Medical Research Council (NHMRC) standards for clinical practice guidelines[43]. Given models of care require quality and safety in healthcare to be met, these guidelines (Table 2) are appropriate and can be transferred and applied to enable a critique of the models of care.

\section{RESULTS}

The search (Figure 1) resulted in six documents being identified (Table 3). Whilst not all documents were titled a 'model of care', they each meet the inclusion criteria. That is, they provided an overarching philosophical framework for burn care from a systems perspective for a specific jurisdiction. They also had the potential to guide the provision of care for Indigenous peoples and children.

\section{Cultural safety analysis}

Overview

Cultural safety was addressed in this review first to ensure the review was not privileging Western biomedical knowledge. 
Table 1 - Cultural safety principles $[41,42]$

\begin{tabular}{|l|l|l|}
\hline Principle & Definition & In-Practice \\
\hline Reflexivity & reflect on practice, mutual respect & $\begin{array}{l}\text { established processes for health } \\
\text { professionals to actively reflect on } \\
\text { practice }\end{array}$ \\
\hline Dialogue & true engagement and consultation & $\begin{array}{l}\text { building rapport and dialogue with family } \\
\text { alongside consideration of kinship } \\
\text { arrangements and decision making } \\
\text { structures, particularly as they relate to } \\
\text { children }\end{array}$ \\
\hline Power & $\begin{array}{l}\text { minimising power differentials and maintaining } \\
\text { human dignity }\end{array}$ & $\begin{array}{l}\text { including Indigenous health workers in } \\
\text { multidisciplinary teams }\end{array}$ \\
\hline Decolonisation & $\begin{array}{l}\text { acknowledging the key role of a colonising } \\
\text { history in contemporary health outcomes for } \\
\text { Aboriginal and Torres Strait Islander peoples }\end{array}$ & $\begin{array}{l}\text { mechanisms to address issues of } \\
\text { implicit bias amongst multidisciplinary } \\
\text { team members }\end{array}$ \\
\hline $\begin{array}{l}\text { provide care that is regardful of culture and } \\
\text { equity in health outcomes } \\
\text { challenges the status quo of providing care that } \\
\text { is regardless of culture }\end{array}$ & $\begin{array}{l}\text { patient-centred care; where the context } \\
\text { for the child and their family drives care } \\
\text { decisions }\end{array}$ \\
\hline Regardful care
\end{tabular}

Table 2 - NHMRC standards for clinical practice guidelines [43]

\begin{tabular}{|c|c|}
\hline & Standards \\
\hline $\begin{array}{l}\text { Clinical } \\
\text { justification }\end{array}$ & provide guidance on a clearly defined clinical problem based on an identified need \\
\hline Multidisciplinary & $\begin{array}{l}\text { be developed by a multidisciplinary group that includes relevant experts, end users and } \\
\text { consumers affected by the clinical practice guideline }\end{array}$ \\
\hline Conflicts & $\begin{array}{l}\text { include a transparent process for declaration and management of potential conflicts of } \\
\text { interest by each member of the guideline development group }\end{array}$ \\
\hline Scientific evidence & $\begin{array}{l}\text { be based on the systematic identification and synthesis of the best available scientific } \\
\text { evidence }\end{array}$ \\
\hline Recommendations & $\begin{array}{l}\text { make clear and actionable recommendations in plain English for health professionals } \\
\text { practising in an Australian healthcare setting }\end{array}$ \\
\hline Navigation & be easy to navigate for end-users \\
\hline Consultation & $\begin{array}{l}\text { undergo a process of public consultation and independent external clinical expert review; } \\
\text { and }\end{array}$ \\
\hline Dissemination & incorporate a plan for dissemination including issues for consideration in implementation \\
\hline
\end{tabular}


Deductive analysis was used to assess how each of the principles introduced in Table 1 were addressed in the identified models of care (Table 4). The analysis identified marked differences between documents with respect to recording the principles of cultural safety, with both documentation of both direct and indirect guidance for healthcare professionals providing care that may/may not be experienced as culturally safe.

\section{Principles}

Only two of the documents $[44,45]$ addressed all five cultural safety principles and not one principle was addressed by all six documents. Reflexivity examples were found in four models of care[44-47] and highlighted the need for health professionals to reflect on their practice, however were not specifically focused on Indigenous or other cultural needs. Quality improvement activities were at the core of reflexivity. Almost all of the documents addressed the cultural safety principle of dialogue[44-47, 49]. 'Dialogue' is a principle in this review that refers to health service and professional ability to partake in and enable engagement and consultation with patients and families. Concepts of dialogue in the documents related to all aspects of the burn patient care journey; prevention[46], admission[49], inpatient[44, 45, 47], discharge[44, 47, 49] and rehabilitation[44, 47].

The concept of power as a cultural safety principle in minimising power differentials and maintaining human dignity was identified in almost all of the models[44, 45, 47-49]. At the core of this principle, was the empowerment of patients and their family. The power relations that models of care set-up between clinicians and families, however makes true power equilibrium unlikely. Furthermore, the influence of power on healthcare interactions may make empowerment doubtful.

Almost all of the documents[44-46, 48] indirectly considered decolonisation by acknowledging the key role of a colonising history in contemporary health outcomes for Indigenous peoples. The models mostly described consideration of factors beyond having a purely medical focus and providing equitable care as addressing the cultural safety decolonisation principal. All documents addressed the provision of regardful care including the provision of holistic care[44, 45] and culturally sensitive care[47].

\section{NHMRC standards for clinical practice guidelines analysis}

\section{Overview}


Deductive analysis was used to assess how the documents met the NHMRC standards for clinical practice guidelines. 
Table 3 - Identified documents reviewed

\begin{tabular}{|c|c|c|c|c|}
\hline Origin & Contributor/Author & Title & Date & Focus \\
\hline Europe & $\begin{array}{l}\text { European Burns } \\
\text { Association[44] }\end{array}$ & $\begin{array}{l}\text { European Practice } \\
\text { Guidelines for } \\
\text { Burn Care }\end{array}$ & $\begin{array}{l}\text { Version } 3 \\
2015\end{array}$ & $\begin{array}{l}\text { Guidelines applicable for adults } \\
\text { and/or children with a burn injury. }\end{array}$ \\
\hline $\begin{array}{l}\text { United } \\
\text { Kingdom }\end{array}$ & $\begin{array}{l}\text { National Network for } \\
\text { Burn Care[45] }\end{array}$ & $\begin{array}{l}\text { National Burn } \\
\text { Care Standards }\end{array}$ & $\begin{array}{l}\text { Revised } \\
\text { January } \\
2013\end{array}$ & $\begin{array}{l}\text { Standards cover the whole of the } \\
\text { burn care pathway and take } \\
\text { account of the specific needs of } \\
\text { children and adults. }\end{array}$ \\
\hline Australia & $\begin{array}{l}\text { Department of Health, } \\
\text { State of Western } \\
\text { Australia, Injury and } \\
\text { Trauma Health } \\
\text { Network[46] }\end{array}$ & $\begin{array}{l}\text { Burn Injury Model } \\
\text { of Care }\end{array}$ & 2009 & $\begin{array}{l}\text { Proposed models of care for Burn } \\
\text { Injury for all WA burn injured } \\
\text { patients. Adult and paediatric. }\end{array}$ \\
\hline Australia & $\begin{array}{l}\text { NSW Agency for Clinical } \\
\text { Innovation[47] }\end{array}$ & $\begin{array}{l}\text { NSW Statewide } \\
\text { Burn Injury Service } \\
\text { Model of Care }\end{array}$ & 2011 & $\begin{array}{l}\text { The model of care has been } \\
\text { designed to address the provision } \\
\text { of burn care for adult and paediatric } \\
\text { patients. Where specific } \\
\text { requirements for burn care for } \\
\text { paediatric patients have been } \\
\text { identified, these have been } \\
\text { indicated in the relevant areas of } \\
\text { the model. }\end{array}$ \\
\hline Australia & $\begin{array}{l}\text { SA Health, Women's } \\
\text { and Children's } \\
\text { Hospital[48] }\end{array}$ & $\begin{array}{l}\text { Paediatric Burns } \\
\text { Service Guidelines }\end{array}$ & $\begin{array}{l}\text { Updated } \\
2014\end{array}$ & $\begin{array}{l}\text { The Paediatric Burns Service is } \\
\text { responsible for inpatient and } \\
\text { outpatient treatment of children up } \\
\text { to } 16 \text { years of age. }\end{array}$ \\
\hline Canada & $\begin{array}{l}\text { The Montreal Children's } \\
\text { Hospital[49] }\end{array}$ & $\begin{array}{l}\text { The management } \\
\text { of pediatric and } \\
\text { adolescent burn } \\
\text { trauma }\end{array}$ & $\begin{array}{l}\text { Revised } \\
2014\end{array}$ & $\begin{array}{l}\text { Guidelines for the management of } \\
\text { child burn trauma. }\end{array}$ \\
\hline
\end{tabular}


Table 4 - Cultural safety analysis

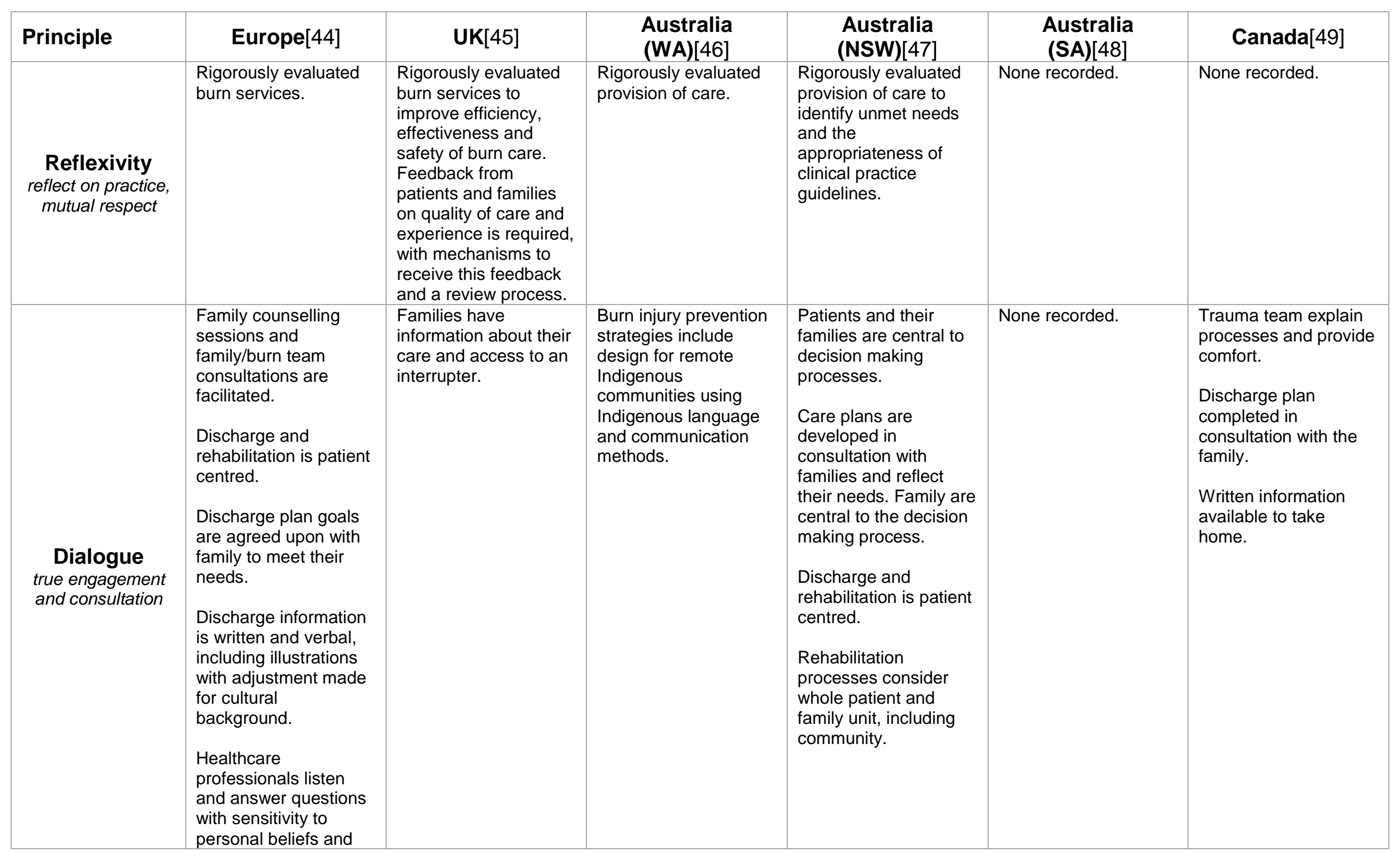




\begin{tabular}{|c|c|c|c|c|c|c|}
\hline & $\begin{array}{l}\text { values. } \\
\text { Care is demonstrated } \\
\text { to families prior to } \\
\text { discharge. }\end{array}$ & & & & & \\
\hline $\begin{array}{c}\text { Power } \\
\text { minimising power } \\
\text { differentials and } \\
\text { maintaining human } \\
\text { dignity }\end{array}$ & $\begin{array}{l}\text { Healthcare } \\
\text { professionals activate } \\
\text { parental coping } \\
\text { strategies. } \\
\text { Healthcare } \\
\text { professional consider } \\
\text { non-pharmacological } \\
\text { pain interventions. }\end{array}$ & $\begin{array}{l}\text { Mutually agreeable } \\
\text { care plans are } \\
\text { developed. }\end{array}$ & None recorded. & $\begin{array}{l}\text { Healthcare } \\
\text { professionals } \\
\text { negotiate care, and } \\
\text { facilitate informed } \\
\text { decision making. }\end{array}$ & $\begin{array}{l}\text { Healthcare } \\
\text { professionals promote } \\
\text { confidence in parental } \\
\text { ability and } \\
\text { psychosocial well- } \\
\text { being of parents to } \\
\text { ensure their optimal } \\
\text { ability to care. }\end{array}$ & $\begin{array}{l}\text { Treatment approach } \\
\text { and plan done with } \\
\text { family. } \\
\text { Family is provided } \\
\text { regular feedback and } \\
\text { encouraged to } \\
\text { participate in } \\
\text { processes. } \\
\text { Healthcare } \\
\text { professionals prepare } \\
\text { the family well for } \\
\text { discharge to home. }\end{array}$ \\
\hline $\begin{array}{l}\text { Decolonisation } \\
\text { acknowledging the } \\
\text { key role of a } \\
\text { colonising history in } \\
\text { contemporary } \\
\text { health outcomes } \\
\text { for Aboriginal and } \\
\text { Torres Strait } \\
\text { Islander peoples }\end{array}$ & $\begin{array}{l}\text { Full consideration of } \\
\text { patient and caregiver } \\
\text { factors and an } \\
\text { awareness of the } \\
\text { impact, complications } \\
\text { and contraindications } \\
\text { of various treatment } \\
\text { modalities are made } \\
\text { when implementing } \\
\text { scar management } \\
\text { regimes. } \\
\text { When discharging, } \\
\text { healthcare } \\
\text { professionals take into } \\
\text { account the family's } \\
\text { ability to care and the } \\
\text { situation at home. }\end{array}$ & $\begin{array}{l}\text { Service and healthcare } \\
\text { professional } \\
\text { compliance with } \\
\text { documented standards } \\
\text { ensures equitable } \\
\text { care. }\end{array}$ & $\begin{array}{l}\text { Prevention strategies } \\
\text { use local research and } \\
\text { consult with } \\
\text { Indigenous } \\
\text { communities to } \\
\text { develop Indigenous } \\
\text { specific burn injury } \\
\text { strategies. } \\
\text { An Aboriginal Health } \\
\text { Impact Statement } \\
\text { stated to have } \\
\text { considered the needs } \\
\text { and interests of } \\
\text { Aboriginal people. }\end{array}$ & None recorded. & $\begin{array}{l}\text { Healthcare } \\
\text { professionals facilitate } \\
\text { a psychosocial } \\
\text { assessment that } \\
\text { includes past } \\
\text { experiences of trauma, } \\
\text { family dynamics, } \\
\text { cultural and socio- } \\
\text { economic factors, } \\
\text { barriers to coping and } \\
\text { family strengths and } \\
\text { supports. } \\
\text { Healthcare } \\
\text { professionals support } \\
\text { families with aspects } \\
\text { which have been } \\
\text { impacted by the child's } \\
\text { injury and admission to } \\
\text { hospital. }\end{array}$ & None recorded. \\
\hline $\begin{array}{l}\text { Regardful care } \\
\text { provide care that is } \\
\text { regardful of culture } \\
\text { and challenges the }\end{array}$ & $\begin{array}{l}\text { Burn care, including } \\
\text { care plans and patient } \\
\text { management, follows a } \\
\text { holistic approach. }\end{array}$ & $\begin{array}{l}\text { Families have access } \\
\text { to a Patient Advisory } \\
\text { Liaison Service or } \\
\text { equivalent and spiritual }\end{array}$ & $\begin{array}{l}\text { E-health technologies } \\
\text { are used to alleviate } \\
\text { distance, transport, } \\
\text { accommodation and }\end{array}$ & $\begin{array}{l}\text { Burn care meets the } \\
\text { patient's needs. } \\
\text { Burn care follows a }\end{array}$ & $\begin{array}{l}\text { The social worker } \\
\text { undertakes a thorough } \\
\text { psychosocial } \\
\text { assessment in order to }\end{array}$ & $\begin{array}{l}\text { Objective of model of } \\
\text { care to provide patient } \\
\text { and family focused } \\
\text { care. }\end{array}$ \\
\hline
\end{tabular}




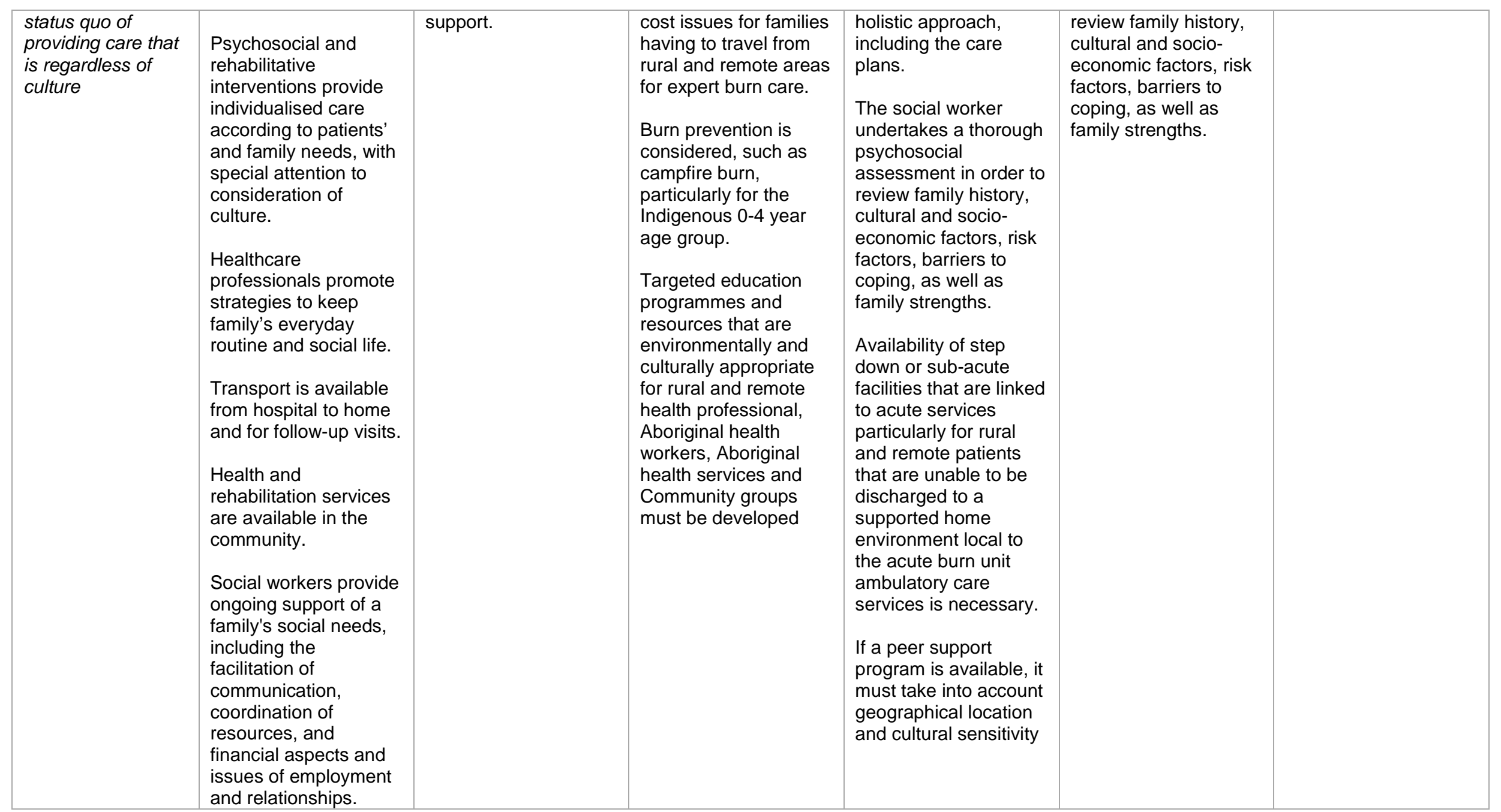


Table 5 - NHMRC Standards analysis

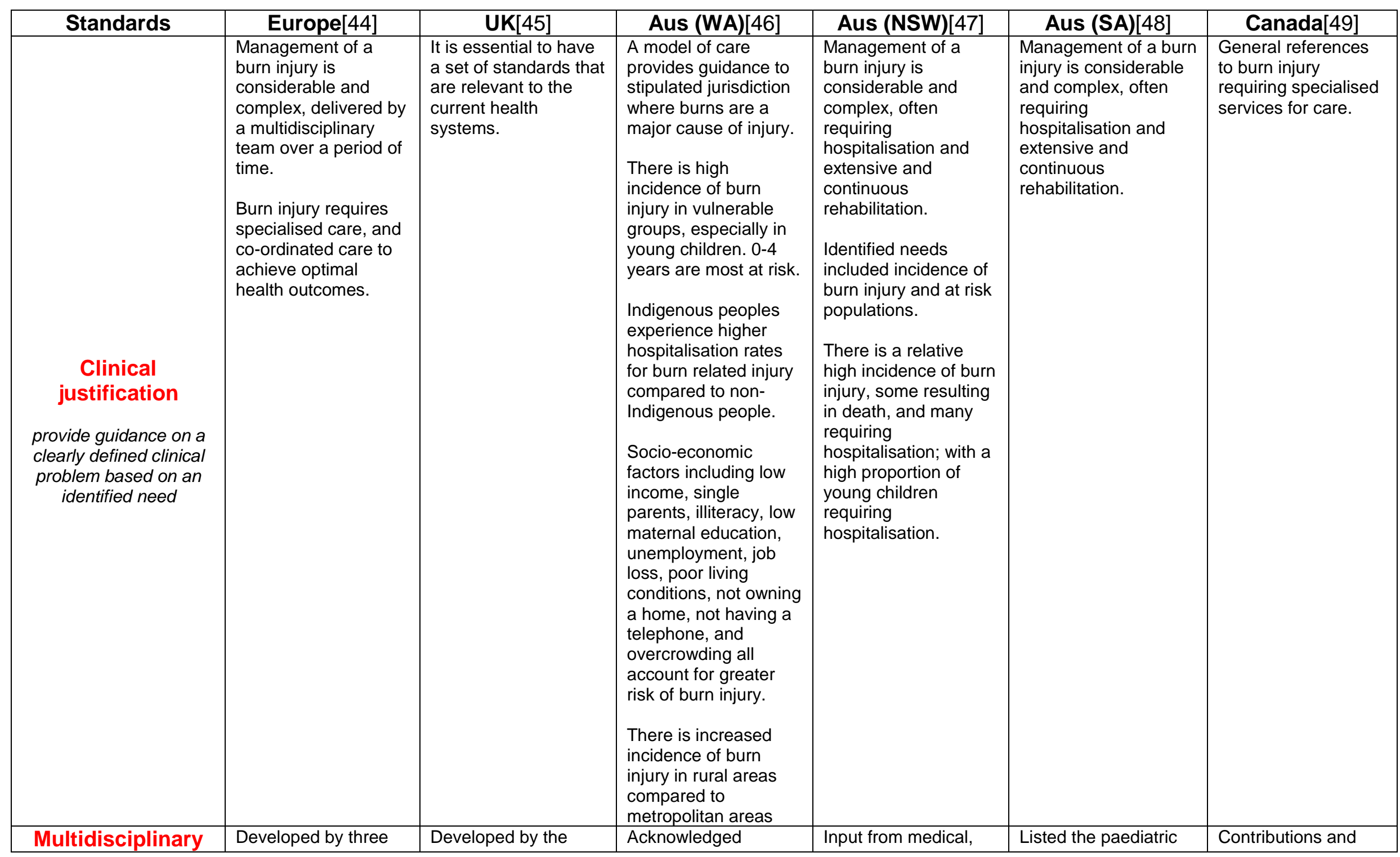




\begin{tabular}{|c|c|c|c|c|c|c|}
\hline $\begin{array}{c}\text { be developed by a } \\
\text { multidisciplinary group } \\
\text { that includes relevant } \\
\text { experts, end users and } \\
\text { consumers affected by } \\
\text { the clinical practice } \\
\text { guideline }\end{array}$ & $\begin{array}{l}\text { committees, had } \\
\text { members across } \\
\text { several different } \\
\text { countries in Europe } \\
\text { and comprised } \\
\text { medical, nursing and } \\
\text { allied health } \\
\text { professionals. }\end{array}$ & $\begin{array}{l}\text { Burn Care Networks } \\
\text { for England and } \\
\text { Wales, NHS } \\
\text { Specialised } \\
\text { Commissioners, } \\
\text { Patient } \\
\text { Representatives and } \\
\text { the British Burn } \\
\text { Association. } \\
\text { Comments from the } \\
\text { wider burns } \\
\text { community by } \\
\text { circulating the draft } \\
\text { revised standards to } \\
\text { the BBA membership. } \\
\text { Although many people } \\
\text { contributed towards } \\
\text { these revisions the } \\
\text { majority of the work } \\
\text { was undertaken by an } \\
\text { expert } \\
\text { multidisciplinary } \\
\text { group. } \\
\text { Multidisciplinary team } \\
\text { consisted of medical, } \\
\text { nursing allied health, } \\
\text { quality consultants, } \\
\text { Patient Organisation } \\
\text { Representative, burn } \\
\text { database personnel. }\end{array}$ & $\begin{array}{l}\text { contribution of } \\
\text { representatives from } \\
\text { the: WA adult and } \\
\text { paediatric burn unit; } \\
\text { Injury Prevention } \\
\text { Working Group; Injury } \\
\text { Control Council of } \\
\text { WA; WA Drug and } \\
\text { Alcohol Office; } \\
\text { Kidsafe WA; WA } \\
\text { Country Health } \\
\text { Service South West } \\
\text { Health Region; Royal } \\
\text { Life Saving Society } \\
\text { WA; and the DoHWA } \\
\text { Population Health } \\
\text { Division and Health } \\
\text { Network Branch. }\end{array}$ & $\begin{array}{l}\text { nursing and allied } \\
\text { health clinicians } \\
\text { involved in the care of } \\
\text { patients with severe } \\
\text { burn injury and burn } \\
\text { survivors. One } \\
\text { consumer was listed. }\end{array}$ & $\begin{array}{l}\text { burns service } \\
\text { multidisciplinary team; } \\
\text { consisting of medical, } \\
\text { nursing and allied } \\
\text { health. }\end{array}$ & $\begin{array}{l}\text { collaboration was } \\
\text { with a team of } \\
\text { multidisciplinary } \\
\text { experts and end } \\
\text { users. }\end{array}$ \\
\hline $\begin{array}{c}\text { Conflicts } \\
\text { include a transparent } \\
\text { process for declaration } \\
\text { and management of } \\
\text { potential conflicts of } \\
\text { interest by each } \\
\text { member of the guideline } \\
\text { development group }\end{array}$ & None recorded. & None recorded. & None recorded. & None recorded. & None recorded. & None recorded. \\
\hline $\begin{array}{l}\text { Scientific } \\
\text { evidence }\end{array}$ & $\begin{array}{l}\text { No systematic } \\
\text { process documented. }\end{array}$ & $\begin{array}{l}\text { No systematic } \\
\text { process documented. }\end{array}$ & $\begin{array}{l}\text { No systematic } \\
\text { process documented. }\end{array}$ & $\begin{array}{l}\text { A health corporation } \\
\text { engaged healthcare } \\
\text { professionals, }\end{array}$ & $\begin{array}{l}\text { No systematic process } \\
\text { documented. }\end{array}$ & $\begin{array}{l}\text { No systematic } \\
\text { process } \\
\text { documented. }\end{array}$ \\
\hline
\end{tabular}




\begin{tabular}{|c|c|c|c|c|c|c|}
\hline $\begin{array}{c}\text { be based on the } \\
\text { systematic identification } \\
\text { and synthesis of the } \\
\text { best available scientific } \\
\text { evidence }\end{array}$ & & & & $\begin{array}{l}\text { managers and the } \\
\text { wider community to } \\
\text { design, promote and } \\
\text { implement. }\end{array}$ & & \\
\hline $\begin{array}{l}\text { Recommendations } \\
\text { make clear and } \\
\text { actionable } \\
\text { recommendations in } \\
\text { plain English for health } \\
\text { professionals practising } \\
\text { in an Australian health } \\
\text { care setting }\end{array}$ & $\begin{array}{l}\text { Provided a set of } \\
\text { minimum level burn } \\
\text { care requirements, } \\
\text { and included } \\
\text { checklists and } \\
\text { documented the } \\
\text { evidence for any } \\
\text { recommendations } \\
\text { made. }\end{array}$ & $\begin{array}{l}\text { Organised into seven } \\
\text { clear sections. } \\
\text { Included the evidence } \\
\text { required to achieve } \\
\text { compliance to the } \\
\text { standards. }\end{array}$ & $\begin{array}{l}12 \text { recommendations } \\
\text { regarding burn care } \\
\text { from an overall } \\
\text { jurisdictional service } \\
\text { perspective. } \\
\text { Recommendations for } \\
\text { healthcare } \\
\text { professionals were } \\
\text { clear, in plain English } \\
\text { with flowcharts. }\end{array}$ & $\begin{array}{l}\text { Provided an initial } \\
\text { framework outlining } \\
\text { model, followed by } \\
\text { clear overarching } \\
\text { burn injury } \\
\text { management } \\
\text { recommendations for } \\
\text { specific jurisdiction. }\end{array}$ & $\begin{array}{l}\text { Included flowcharts, } \\
\text { diagrams and referral } \\
\text { documents. Clear } \\
\text { clinical care pathways } \\
\text { for emergency } \\
\text { management, burn } \\
\text { wound assessment, } \\
\text { wound management, } \\
\text { infection control, pain } \\
\text { relief and } \\
\text { physio/occupational } \\
\text { therapy. }\end{array}$ & $\begin{array}{l}\text { Included flowcharts, } \\
\text { diagrams, protocols } \\
\text { and discharge } \\
\text { documents. }\end{array}$ \\
\hline $\begin{array}{c}\text { Navigation } \\
\text { be easy to navigate for } \\
\text { end-users }\end{array}$ & $\begin{array}{l}\text { Document aligned to } \\
\text { a literature review }\end{array}$ & $\begin{array}{l}\text { Recommendations } \\
\text { made as to how to } \\
\text { achieve the standards } \\
\text { from a service } \\
\text { perspective. }\end{array}$ & $\begin{array}{l}\text { Flowcharts and } \\
\text { images. }\end{array}$ & $\begin{array}{l}\text { Clear and set into } \\
\text { easily defined areas } \\
\text { of burn care } \\
\text { recommendations. }\end{array}$ & $\begin{array}{l}\text { Used flowcharts and } \\
\text { images, and included } \\
\text { referral forms and } \\
\text { contact details. }\end{array}$ & $\begin{array}{l}\text { Used flowcharts and } \\
\text { included protocol } \\
\text { documents for } \\
\text { specific healthcare } \\
\text { professions. }\end{array}$ \\
\hline $\begin{array}{l}\text { Consultation } \\
\text { undergo a process of } \\
\text { public consultation and } \\
\text { independent external } \\
\text { clinical expert review; }\end{array}$ & $\begin{array}{l}\text { Invitation to all of } \\
\text { those involved in burn } \\
\text { care or interested } \\
\text { people to expression } \\
\text { their opinions. }\end{array}$ & $\begin{array}{l}\text { Sought comments } \\
\text { from the wider burns } \\
\text { community by } \\
\text { circulating draft } \\
\text { revised standards to } \\
\text { the burn association } \\
\text { membership. }\end{array}$ & $\begin{array}{l}\text { None recorded, } \\
\text { however proposed } \\
\text { model of care only. }\end{array}$ & $\begin{array}{l}\text { Initial development } \\
\text { was undertaken by } \\
\text { the NSW Severe Burn } \\
\text { Service } \\
\text { Implementation } \\
\text { Group. 2nd edition } \\
\text { reviewed by the ACl } \\
\text { Burn Injury Network } \\
\text { (Statewide Burn Injury } \\
\text { Service). } \\
\text { Development of the } \\
\text { Model of Care } \\
\text { included input from } \\
\text { medical, nursing and } \\
\text { allied health clinicians } \\
\text { involved in the care of } \\
\text { patients with severe } \\
\text { burn injury and burn } \\
\text { survivors. }\end{array}$ & None recorded. & None recorded. \\
\hline
\end{tabular}




\begin{tabular}{|c|l|l|l|l|l|l|}
\hline Dissemination & None recorded. & None recorded. & $\begin{array}{l}\text { Extensive list } \\
\text { recorded. }\end{array}$ & None recorded. & None recorded. & None recorded. \\
$\begin{array}{c}\text { incorporate a plan for } \\
\text { dissemination including } \\
\text { issues for consideration } \\
\text { in implementation }\end{array}$ & & & & & \\
\hline
\end{tabular}


The analysis found the guidelines were met differently across the documents, with no one document meeting all eight. All documents contained clear and actionable recommendations for health services and healthcare professionals, however the processes used for development of the documents were mostly unrecorded.

\section{Standards}

All documents highlighted some clinical justification for a burn injury model of care and all provided guidance for burn injury management from injury through to rehabilitation by specialists in multidisciplinary teams. Two of the five documents $[46,47]$ specifically identified need for a burn injury model of care, and other needs included incidence of burn injury and at risk populations. All documents were developed by teams of multidisciplinary healthcare professionals, with one document listing a consumer[47]. It was not clear how the teams contributed or how the contributors were designated to this role. The NHMRC [43] calls for a declaration of conflicts; however, there were no declaration of potential writer conflicts in the development groups, nor documentation of management of potential conflicts by contributors in any of the reviewed documents. Furthermore, it was not clear if there was equal participation between contributors as only one of the documents[47] recorded a systematic process of development [47].

The NHMRC[43] also require models be based on the best available scientific evidence, however there was inconsistency between documents with respect to the references used and not all aspects of care were referenced. One document[44] highlighted a lack of rigorous evidence for some aspects of burn care and suggested clinical consensus was used to inform practice. Conversely another document[47] reported the application of evidencebased practice was essential to achieve positive patient outcomes.

The documents all made specific recommendations in plain English relevant to their jurisdiction for healthcare professionals. The Canadian[49] document was available in French (a legal requirement in Canada), however no other model was offered in a different language. The end-users of these documents are the health service and healthcare professionals. For ease of navigation, all documents were separated into different sections either by profession or burn management stage, however overall presentation and inclusion of detail varied. Different methods of consultation and review were implemented in the documents. Three documents $[44,45,47]$ that sought review by wider membership did not report a process for responding to feedback. Two documents[46, 48] did not specify a consultation process, although one of these was a proposed model of care and may engage a consultation process further on. The incorporation of a plan for dissemination including 
issues for consideration in implementation was not recorded in any of the documents, aside from one[46]. This document was a proposed model and recorded an extensive implementation list. In a report by the Government of Western Australia[50], the burn injury model of care has reached a level of substantial implementation; meaning that most of the recommendations of the model of care have been implemented.

\section{DISCUSSION}

This review provides a unique critique of burn injury models of care with a focus on Indigenous children, from a quality and safety perspective using both Indigenous health knowledge and Western biomedical knowledge. The review is limited by the possibility that other burn injury models of care may exist but were inaccessible for the purpose of this review. Furthermore, it is acknowledged that health services and healthcare professionals are influenced by other documents that may not fit within the confines of a model of care per se, but rather sit alongside. This is especially true for profession specific guidance and related regulatory requirements. Lastly, no child specific cultural safety analysis framework was identified for use in the analysis.

Burn care can be complex and require a multidisciplinary approach over extended periods. The care of a child in the context of a family and taking into consideration growth and development heightens the complexities of burn care. The care of Indigenous peoples requires the inclusion of holistic approaches to care that sit outside of Western biomedical models. There is clear opportunity in burn care for improvement, with increased focus on patient needs[46].

Burn injury models of care are multifaceted documents that guide the way burn care is delivered in a specific jurisdiction[44-49]. It is implicit these models of care address quality and safety across all aspects, including in their development in order to facilitate such care. Culturally competent models of care consider concepts of health that extend beyond the Western biomedical health system. This guidance allows for the provision of equitable care; in contrast to care being based entirely on equality. This review demonstrated that publicly available burn injury models of care do not address all aspects of quality and safety.

\section{Quality in models of care}

The NHMRC standard for clinical practice guidelines[43] provides a framework to analyse burn injury models of care from a quality perspective; however this framework lacked consideration of culture. Overall, quality was difficult to determine due key indicators of 
quality being in part or completely absent in the documents addressed by the review. There were no clear descriptions of how the synthesis of best available evidence informed the documents, making comparisons difficult. Best practice recommendations do exist[51-57], however where and how these recommendations have translated into the reviewed burn injury models of care was unclear.

The American Burn Association facilitates a verification process for burn centres detailing overall burn care systems including outcomes, infrastructure and process[58] to enhance quality. Although not US based, none of the models of care reviewed made reference to this standard, or similar accreditation type processes. Furthermore, whilst the models seemed mostly to be created by teams of specialist clinicians, for most, they did not document a process of consultation with external parties. Consultation with external parties, including consumers is important for quality and transparency and provides the opportunity for fair contribution and different knowledge perspectives to be considered. This raises the question that if models of care are mostly clinician informed, how do they incorporate evidence and do they meet the prescribed standards of quality for each given jurisdiction and/or population groups?

\section{Safety in Models of Care}

Health outcomes for Indigenous people are more likely to be enhanced when healthcare is experienced as culturally safe[33,59]. This review demonstrated burn injury models of care address only some of the principles of cultural safety. It is anticipated that if a burn injury model of care provides opportunities for health services and healthcare professionals to enact care that is culturally competent, there would seem potential for better outcomes following a burn injury. Experiences of culturally safe burn care may help ensure improved and ultimately more economical long term outcomes for Indigenous children including through the potential for reduced loss to follow-up, increased access to rehabilitation, more efficient services and increased effectiveness. Consideration of kinship arrangements is necessary to achieve these outcomes. For example, considering beyond a western nuclear family model to a more collective community focus. In the Australian context, the Cultural Respect Framework[60] highlights relevant quality healthcare items relating to Aboriginal and Torres Strait Islander people which includes amongst many items, mechanisms to support the delivery of culturally safe healthcare. It is unclear how the Australian burn injury models of care address items in this framework. Similarly, the ability of health systems and services internationally in providing mechanisms for culturally safe burn injury management is vague. 
There appeared to be limited or no cultural consultation in the models of care reviewed and in terms of their development, it is uncertain if any Indigenous people contributed or if they did, in what capacity. One model[46] reported needing to consult with Aboriginal peoples regarding the development of burn injury prevention materials and included an incomplete Aboriginal impact statement. Similarly, where the models provided an opportunity for healthcare professionals to provide care with regard to culture, directions were mostly implicit and not mandatory.

Another emphasis of cultural safety is on the healthcare interaction. While burn injury models of care provide guidance to health services and healthcare professionals from which to enact burn care, the delivery of care and subsequently the healthcare interaction is dependent on the individual. It is the individual health professional's level of empathy and capacity for reflective practice in providing healthcare that is or is not experienced as culturally safe[34]. These qualities contribute to health professionals' understanding of the process of culture, identity and wellbeing and includes reflexivity whereby the health professional acknowledges how power imbalances or relationships contribute to culturally unsafe practice[61]. Therefore, although cultural safety is conceptualised in the healthcare interaction, it is vital that cultural safety principles be manifest in health system and service documents, which in this instance are the burn injury models of care. It is the combination of the ability of burn injury models of care to facilitate safe, high-quality care and the individual health professionals' implementation of that guidance that is a true measure of cultural safety. In addition to the lack of cultural safety in the burn injury models of care reviewed how these prescriptions of care are enacted by healthcare professionals for each jurisdiction has not been explored. As a result, it remains unclear if Indigenous children are receiving safe, high quality burn care from a system, service or individual level.

It is well documented that Indigenous peoples' and those living in rural and remote areas experience burn injury at a higher rate than people living in metropolitan areas[6,62]. This review also recognised that burn injury models of care provide guidance for the burn care of Indigenous children residing in rural and remote geographical locations without adequate consideration of the availability of healthcare and other services in these communities. Patient assisted transport schemes were addressed in the models and do provide support to those families who experience difficulties related to geographical isolation. These schemes do not address an Indigenous person's connection to country and family, and it is unclear in the models whether or how services might be accessed closer to home in order to minimise the need for travel. Providing services in regional and remote areas can be expensive, 
however there is likely to be a significant impact on health and wellbeing when multiple family members are away from home for extended periods of time.

\section{What should a burn injury model of care include?}

This review highlighted gaps related to safety and quality in the current burn injury models of care that inform healthcare provided to Indigenous children. The development of a model of care needs consultation with key stakeholders and consumers of care. Furthermore, incorporation of all health knowledge resources and the combination of clinical and cultural aspects is imperative as being culturally secure is critical for Indigenous children's wellbeing. Milroy's[63] dimensions of holistic health: physical, psychological, social, spiritual and cultural could provide the basis for a model of care and has culture as the centre of health as per current National Aboriginal and Torres Strait Islander Health Plan[64]. A focus on 'patient-centred care that is respectful of, and responsive to the preferences, needs and values of consumers' will help facilitate high quality and culturally safe models of burn care[65].

How do we develop a safe, high quality model of care for Indigenous children? The development of a model of care needs consultation with key stakeholders and consumers of care. Cultural safety needs to be reflected and clearly articulated in the documents that guide burn care. To enable such a purposeful approach to cultural safety, expectations of cultural safety need to be embedded in policy, health systems and at service levels. To facilitate the development of such guidance, an accurate account of what guides the burn care delivered in tertiary paediatric burn units across Australia is needed; along with how this guidance is implemented. Durie's principles of research at the interface of knowledge systems[31] are well aligned to the development of a safe, high quality burn injury model of care. These principles include: mutual respect, with recognition of the validity of each system of knowledge; shared benefits, where Indigenous communities share in the benefits; human dignity with cultural and spiritual beliefs and practices reinforced; and discovery where innovation and exploration using Indigenous methodologies and scientific methods work together.

With a safe, high quality burn injury model of care, implemented by cultural competent healthcare professionals, there is the opportunity for equitable health outcomes. There is the chance that a child's readmission to hospital for infection will not occur and a surgeon's skin graft will more likely be successful. Along with these better health outcomes, the effectiveness and efficiency of burn care may be enhanced, and benefits to health system may be achieved. 


\section{CONCLUSION}

This review has highlighted gaps concerning safety and quality in documented care pathways for Indigenous peoples' who sustain a burn injury and require burn care, and highlights the need for the investigation of current practices in burn units who treat Aboriginal and Torres Strait Islander children. Some, but not all, aspects of cultural competence were addressed in the models. The question still remains, is cultural safety facilitated or mitigated by the application of the guidance? An investigation of current health system and service and practices in the burn units across Australia will provide the basis for the development of a national burn injury model of care that is informed on the premise of mutual respect, shared benefits, human dignity and discovery.

\section{ACKNOWLEDGEMENTS}

This project is guided by an Aboriginal and Torres Strait Islander reference committee, comprising Aboriginal and Torres Strait Islander investigators, study participants and stakeholders. We acknowledge their expertise and guidance. The project is funded by the National Health and Medical Research Council of Australia (grant number APP1059038). Dr Hunter is supported by a NSW Health Early Mid Career Fellowship. 


\section{REFERENCE LIST}

1. Peck, M.D., Epidemiology of burns throughout the world. Part I: Distribution and risk factors. Burns, 2011. 37(7): p. 1087-1100.

2. Sadeghi-Bazargani, H., et al., Individual-level predictors of inpatient childhood burn injuries: a case-control study. BMC public health, 2016. 16(1): p. 1.

3. Akita, S., et al., Analysis of pediatric burns in Nagasaki University from 1983 to 2002. Burns, 2005. 31(8): p. 1041-4.

4. Alnababtah, K., S. Khan, and R. Ashford, Socio-demographic factors and the prevalence of burns in children: an overview of the literature. Paediatrics and international child health, 2016. 36(1): p. 45-51.

5. Brussoni, M., et al., Injuries to Aboriginal populations living on-and off-reserve in metropolitan and non-metropolitan areas in British Columbia, Canada: Incidence and trends, 1986-2010. BMC public health, 2016. 16(1): p. 1.

6. Australian Institute of Health and Welfare, The health and welfare of Australia's Aboriginal and Torres Strait Islander people, an overview, in Cat. no. IHW 42. Canberra: AIHW. 2011.

7. Burns Registry of Australia and New Zealand, Annual Report 1st July 2013-30th June. 2014.

8. Tovell, A., et al., Hospital separations due to injury and poisoning, Australia 2009-10. Injury research and statistics series no. 69. , Australian Institute of Health and Welfare, Editor. 2012: Canberra.

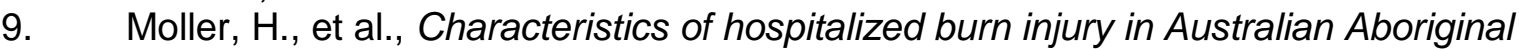
and non-Aboriginal children: a population data linkage study. Medical Journal of Australia, 2017.

10. Anderson, I., et al., Indigenous and tribal peoples' health (The Lancet-Lowitja Institute Global Collaboration): a population study. The Lancet, 2016. 388(10040): p. 131-157.

11. Al-Mousawi, A.M., et al., Burn teams and burn centers: the importance of a comprehensive team approach to burn care. Clinics in plastic surgery, 2009. 36(4): $p$. 547-554.

12. Esselman, P.C., Burn rehabilitation: an overview. Archives of physical medicine and rehabilitation, 2007. 88(12): p. S3-S6.

13. Foster, K., Clinical guidelines in the management of burn injury: a review and recommendations from the organization and delivery of burn care committee. Journal of Burn Care \& Research, 2014. 35(4): p. 271-283.

14. Queensland Government, Changing models of care framework, Queensland Health, Editor. 2004.

15. Davidson, P., et al., Beyond the rhetoric: what do we mean by a'model of care'? 2006.

16. Smith, A.C., J.-A. Kairl, and R. Kimble, Post-acute care for a paediatric burns patient in regional Queensland. Journal of telemedicine and telecare, 2002. 8(5): p. 302-304.

17. Smith, A.C., et al., A review of three years experience using email and videoconferencing for the delivery of post-acute burns care to children in Queensland. Burns, 2004. 30(3): p. 248-252.

18. Finlay, V., et al., Evaluation of a streamlined model of care for minor burn patients. J Burn Care Res, 2014. 35(4): p. 342-8.

19. Kim, L.K., H.C. Martin, and A.J. Holland, Medical management of paediatric burn injuries: best practice. Journal of paediatrics and child health, 2012. 48(4): p. 290295.

20. National Burn Care Review Committee, Standards and strategy for burn care: a review of burn care in the British Isles. 2001: Manchester UK. p. 39.

21. Joynt, K.E., et al., Quality of care and patient outcomes in critical access rural hospitals. Jama, 2011. 306(1): p. 45-52. 
22. Finlay, V., et al., Towards more efficient burn care: Identifying factors associated with good quality of life post-burn. Burns 2015. 41: p. 1397 - 1404.

23. Wong, K., et al., Early in -hospital management of burn injuries in Australia. ANZ journal of surgery, 2004. 74(5): p. 318-323.

24. Health Quality \& Safety Commission New Zealand. Available from: http://www.hqsc.govt.nz/.

25. The United Kingdom National Patient Safety Agency. Available from: http://www.npsa.nhs.uk/.

26. United States of America. The Agency for Healthcare Research and Quality. Available from: http://www.ahrq.gov/.

27. Australian Commission on Safety and Quality in Health Care. Available from: http://www.safetyandquality.gov.au/.

28. Australian Commission on Safety and Quality in Health Care, Australian Safety and Quality Framework for Health Care, in http://www.safetyandquality.gov.au/wpcontent/uploads/2012/01/32296-Australian-SandQ-Framework1.pdf.

29. Australian Commission on Safety and Quality in Health Care. Australian Safety and Quality Goals for Health Care. Available from: http://www.safetyandquality.gov.au/national-priorities/goals/.

30. American Burn Association. Quality Improvement Guidelines for Burn Center Verification. Available from: http://www.ameriburn.org/verification_guidelines.php.

31. Durie, M., Indigenous Knowledge Within a Global Knowledge System. Higher Education Policy, 2005. 18: p. 301-312.

32. Martin, K. and B. Mirraboopa, Ways of knowing, being and doing: A theoretical framework and methods for indigenous and indigenist re-search. Journal of Australian Studies, 2003. 27(76): p. 203-214.

33. Bainbridge, R., et al., Cultural competency in the delivery of health services for Indigenous people: Issue paper no. 13, in Closing the Gap Clearinghouse, Australian Institute of Health and Welfare, Editor. 2015: Canberra.

34. Ramsden, I., Cultural safety and nursing education in Aotearoa and Te Waipounamu, in Unpublished PhD thesis, Victoria University, Wellington. 2002.

35. National Aboriginal Health Orgaization, Cultural Competency and Safety: A Guide for Health Care Administrators, Providers and Educators. 2008: Ottawa, Ontario.

36. Kent, L., H. King, and R. Cochrane, Maternal and child psychological sequelae in paediatric burn injuries Burns, 2000. 26: p. 317-322.

37. Sheridan, R.L., et al., Long-term outcome of children surviving massive burns. Jama, 2000. 283(1): p. 69-73.

38. Sheridan, R.L., et al., The effect of family characteristics on the recovery of burn injuries in children. Journal of trauma and acute care surgery, 2012. 73(3): p. S205S212.

39. Wal, M., et al., Outcome after burns: an observational study on burn scar maturation and predictors for severe scarring. Wound repair and regeneration, 2012. 20(5): p. 676-687.

40. Anzarut, A., et al., Quality-of-life and outcome predictors following massive burn injury. Plastic and Reconstructive Surgery, 2005. 116(3): p. 791-797.

41. Taylor, K. and P. Guerin, Health care and indigenous Australians : cultural safety in practice. 2014.

42. Garvey, G., et al., Is there an Aboriginal bioethic? Journal of Medical Ethics, 2004. 30(6): p. 570-575.

43. National Health and Medical Research Council, Procedures and Requirements for meeting the 2011 NHMRC standard for clinical practice guidelines, Summary for Developers. 2011.

44. European Burns Association, European Practice Guidelines for Burn Care. Version 3. 2015: Hannover, Germany.

45. $\quad$ NHS National Network for Burn Care, National Burn Care Standards. Revised 2013: England and Wales. 
46. Governement of Western Australia. Department of Health. Injury and Trauma Health Network, Burn Injury Model of Care. 2009: Western Australia.

47. ACI NSW Agency for Clinical Innovation, Model of Care NSW Statewide Burn Injury Service. 2011: Sydney, NSW.

48. Government of South Australia. SA Health. Women's and Children's Hospital, Paediatric Burns Service Guidelines. updated 2014.

49. The Montreal Children's Hospital, The management of pediatric and adolescent burn trauma. 2014.

50. Governement of Western Australia, Implementation of models of care and frameworks - progress report 2015, Department of Health, Editor. 2015.

51. Campbell, J., Burn Rehabilitation: Outpatient Model of Care. The Joanna Briggs Institute, 2015.

52. Campbell, J., Burn Rehabilitation: Indigenous Client. The Joanna Briggs Institute, 2015.

53. Campbell, J., Burn Rehabilitation: Inpatient Model of Care. The Joanna Briggs Institute, 2015.

54. Campbell, J., Burn Nursing: Model of Care. The Joanna Briggs Institute, 2015.

55. Chu, V., Burns (Child): Multidisciplinary Management. The Joanna Briggs Institute, 2015.

56. Kavanagh, S., Burn Wound Mangaement: Primary Care Facility. The Joanna Briggs Institute, 2013.

57. Shama, L., Burn Units: Referral. The Joanna Briggs Institute, 2016.

58. American College of Surgeons, Resources for Optimal Care of the Injured Patient, in Chapter 14: Guidelines for Trauma Centers Caring for Burn Patients. 2014: Chicago, IL.

59. Downing, R., E. Kowal, and Y. Paradies, Indigenous cultural training for health workers in Australia. International Journal for Quality in Health Care, 2011: p. mzr008.

60. Australian Health Ministers' Advisory Council's National Aboriginal and Torres Strait Islander Health Standing Committee, Cultural Respect Framework 2016-2026 For Aboriginal and Torres Strait Islander Health, Australian Health Ministers' Advisory Council, Editor. 2016: Canberra, Australia.

61. Richardson, F. and J. Carryer, Teaching cultural safety in a New Zealand nursing education program. Journal of Nursing Education, 2005. 44(5): p. 201.

62. Moller, H., et al., Indigenous and non-Indigenous Australian children hospitalised for burn injuries: a population data linkage study. Med J Aust, 2017. 206(9): p. 392-397.

63. Australian Indigenous Doctors' Association, Health Impact Assessment of the Northern Territory Emergency Response. 2010.

64. Trewin, D., National Aboriginal and Torres Strait Islander Health Survey, Australia, 2004-05. 2006: Australian Bureau of Statistics.

65. Australian Commission on Safety and Quality in Health Care, Patient-centred care: Improving quality and safety by focusing care. 2010. 